Original Research Paper

\title{
E-Government Diffusion in Jordan: Employees' Perceptions Toward Electronic Government in Jordan
}

\author{
Wasfi Alrawabdeh \\ Department of Business Administration, Hashemite University, 13115 Zarqa, Jordan
}

Article history

Received: 22-01-2016

Revised: 01-01-2017

Accepted: 12-01-2017

Email: rawabdeh@hu.edu.jo

\begin{abstract}
A number of countries, in both developed and developing nations, have started e-government programs that aim to provide public services online, improve government procedures and, most importantly, provide improved services for citizens. The aim of this paper is to identify the factors that are currently influencing the development and diffusion of e-government in Jordan as perceived by government employees involved in e-government service delivery. The study also investigates how Jordan government benefit from the generous advantages created by such applications and avoid the barriers that hinder its' implementation. In this research a quantitative survey is used in three key public service agencies in Jordan that include the municipality of Amman, licenses and vehicle department and the tax department. All three selected public agencies were actively involved in e-government and have some transaction level of e-government services. The research identifies nine key factors that are influencing the progress of the national e-government project in Jordan. Ease of use and access to the internet and trust on the system may lead to high levels of confidence among employees' in relation to e-government adoption. The most important benefit that encourage e-government adoption is found to be providing a more reliable service to customers while the most important barrier that inhibit its adoption is found to be the difficulty of maintaining the government websites.
\end{abstract}

Key words: E-Government, Adoption, Benefits, Barriers, Jordan

\section{Introduction}

Today as a result of the revolution that occurred in the technology and telecommunication sector, e-government have emerged and spread rapidly among developed countries and slowly among developing countries such as Jordan (Peng and Kurnia, 2010; Grimsholm and Poblete, 2010; Al-Abdallah, 2013).

Electronic government or e- government has changed the way citizens and businesses interact with their government by increasing the level of access to information and facilitating greater solutions to government services (Ebrahim and Irani, 2005; Hsieh et al., 2013; Krishnan et al., 2013). According to Nassuora and Al-Mushasha (2012; Hsieh et al., 2013), e-government has the potential to revolutionize the performance of governments to better serve its' citizens. Therefore, Egovernment is defined as the use of Internet and the World Wide Web to use the most innovative information and communication technologies to deliver effective and efficient information and services for citizens with more convenient access to government information and services (Arif, 2008; Alsaghier et al., 2009).

\section{E-government Environment in Jordan}

Jordan is a middle-income developing country located in the Middle East and bordered by Israel, Saudi Arabia, Iraq, Syria and the West Bank. Population stands at around 9.5 million, including 2.9 million guests at June 2016 (DOS, 2016). Jordan is a constitutional monarchy headed by King Abdullah II with a representative government. The country is rich in human resources, relatively poor in natural resources and imports most of its food and crude oil from the Arab countries (Ahmad and Zink, 1998). King Abdullah II and his government have realized that the Internet and egovernment technology cannot be diffused in the country without collaboration between the public and the private sector. To pave the way for the adoption of egovernment, the government needs to build a reliable ICT infrastructure and sustainable legal system to encourage the private sector and citizens to adopt the new technology (Molla and Licker, 2005). 
ICT infrastructure is considered a prerequisite for e-government adoption and therefore King Abdullah II, with the collaboration of his government, has initiated the process of reforming the public sector with the aim of increasing liberalization, supporting democracy and enhancing the level of competition in the country (Al-Qirim, 2007). Ultimately, Jordan has taken many steps in this direction, benefiting from the golden opportunity provided by its human resources, which can be a valuable asset to support the development of ICT projects in the country (Al-Jaghoub and Westrup, 2003).

The e-government initiative in Jordan was started in 2000 by the Ministry of Information and Communication Technology (Iddris, 2012). The initiative aimed to give Jordanians the ability to access government information and services irrespective of their location, education, economic situation, or IT ability (Nassuora and AlMushasha, 2012). In addition, the initiative aimed to shift the government's role of information collector to information facilitator by making its services available through the web.

Several Jordanian departments such as the municipality of Amman, Licenses and vehicle department and the tax department have been able to provide their services to the public online since 2005 (Mofleh et al., 2008). All three selected public agencies were actively involved in e-government and have some transaction level of e-government services. Therefore, this research will focus on the factors that influence egovernment adoption in Jordan from the employees' perspectives in those three public entities.

\section{Factors Influencing E-government Adoption in Jordan}

A number of countries, in both developed and developing nations, have started e-government programs that aim to provide public services online, improve government procedures and, most importantly, provide improved services for citizens (Laudon and Traver, 2009; Molla and Licker, 2009; Leonard, 2012; Anas et al. 2014). In regards to the e-government in Jordan, in particular, some researches related to e-government have been published. For example, Anas et al. (2014) have discussed the maturity level of the Jordanian electronic government program from the citizen's perspective and found that citizen's interest in e-government services is declining due to awareness problem. Al Hujran et al. (2013) have studied the factors influencing citizen adoption of e-government in Jordan and found that ease of use, perceived usefulness, satisfaction, trust, responsiveness, reliability and information technology as important factors. Almatarneh (2011) has studied the privacy implications for Information and Communications Technology (ICT) in Jordanian e- government sector and found that only three out of forty government agencies have some sort of guidelines with regard to privacy policies.

Al Shibly and Tadros (2010) have examined the factors that impact e-government acceptance by Jordanian employees and found three factors that have significant influence that include system quality, information quality and perceived ease of use. Another research conducted by Al-Soud and Nakata (2010) have assessed the Jordanian e-government Websites and found that the Jordanian e-government Websites do have a lack of consistency in terms of standards and features due to the absence of different features that could improve interaction with the user. Ciborra and Navarra (2005), focused on the analysis and early design of egovernment solutions in Jordan and found that implementing a general standardized ICT portfolio to support good governance proves to be a difficult task and that there are a number of risks emerging from development aid policies aimed at good governance.

From the literature reviewed about the factors that affect the diffusion of e-government globally and in Jordan, the most important factors affecting egovernment adoption are found to include trust, ease of use and access to internet, information system, relative advantage, sector size, top management support, government structure, trading partners' pressure, efficiency, service quality, regulatory issues. These factors are discussed in details in the following sections.

\section{Trust}

Trust is considered as one of the most critical factors that affect e-government adoption decisions (Carter and Weerakkody, 2008). Trust refers to the user's belief in security and privacy in using electronic transactions via an official government website; also, it gives the perception of users' confidence in the government agency. Al-Khouri and Bal (2007) looked at it in two different ways; on one hand protection of the transactional detail of the customers, on the other hand privacy of personal information of the respondents. According to Aljafri et al. (2013) "Trust" is a term that was used to tackle the issues of security and privacy, which is an attribute that was embraced by e-government and considered critical. Thus, the following hypothesis can be derived:

H1: Trust that involve security and privacy have positive impact on e-government adoption in Jordan

\section{Ease of Use and Access to Internet}

Beynon-Davies (2007; Weerakkody et al., 2007; Sajuyigbe, 2012) found that ease of use and access to the internet has affected the intention to use the internet 
positively. Usability and accessibility of internet, in other words it's the state of believing that using the internet is effortless when an innovation is easily used and understood. Accessibility refers to the ease of attaining information and services offered through an official e-government website (Beynon-Davies, 2007; Weerakkody et al., 2007). All over the world, consumers are most likely chose and accept the usable and acceptable systems over the more complicated ones. Thus, the following hypothesis can be derived:

$\mathrm{H} 2$ : Ease of use and access to internet has a positive impact on e-government adoption in Jordan

\section{Information Technology (IT)}

Information Technology (IT) is the application of technology and telecommunications equipment to safe, retrieve, transmits and manipulate data (Gauld and Goldfinch, 2006; Lin et al., 2011). There are five dimensions of IT capability that include IT infrastructure, IT human resources, IT-related intangible resources, IT co-ordination and IT governance (Wang et al., 2010; Lin et al., 2011). IT has become one of the main elements of managerial reform and electronic government may figure prominently in future governance (Moon, 2002). Thus; the following hypothesis can be derived:

H3: Information Technology (IT) has a positive impact on e-government adoption in Jordan

\section{Relative Advantage}

Relative advantage is the level of innovation perceived as being better than the idea it supersedes (Prajogo and Olhager, 2012). Governments must recognize that the adoption of new technology will either offer solutions to current issues or present new production opportunities, such as increased profits, market share and improved operational performance. Governments adopt new technology such as egovernment when they see a need for that technology, believing it will either take advantage of a business opportunity or close a certain technology gap (Banerjee and Ma, 2012). According to Carter and Belanger (2005) e-government increases the convenience and accessibility of government services and information to citizens. Thus, the following hypothesis can be derived:

H4: Relative advantage has a positive impact on egovernment adoption in Jordan

\section{Sector Size}

Previous research in new technology implementation found government size as an important factor affecting e- government adoption (Moon, 2002; Banerjee and Ma, 2012). A number of studies have found that large sectors are more likely to adopt due to greater resources and knowledge to implement technology and economies of scale (Zhang et al., 2011). The size of public sectors also plays a very important role in determining whether egovernment can be implemented or not. According to Ripolles et al. (2010), the size of an enterprise can influence the decision to adopt or not to adopt egovernment and influence the type of technologies employed. Thus, the following hypothesis can be derived:

H5: Sector size has a positive impact on e-government adoption in Jordan

\section{Top Management Support}

The primary role for top management is to ensure the understanding of good opportunities about new technology development and implementation for the firm long-term strategy (Wang et al., 2010; Lin et al., 2011). Top management support has been identified as crucial element in the acquisition and diffusion of Egovernment. Therefore, top management support and commitment is positively affected e-government adoption. Thus, the following hypothesis can be derived:

H6: Top management support has a positive impact on e-government adoption in Jordan

\section{Government Structure}

According to Alshehri et al. (2012; Krishnan et al., 2013), government structure represent the people who are in the same department and doing the same functions in stable environment division. Government's structure plays an important role in attracting the adoption of e-government. Government's structure is the formal system of task and reporting relationships that controls, coordinate and motivates employees so that they cooperate and work together to achieve organizational goals. Thus, the following hypothesis can be derived:

H7: Government structure has a positive impact on egovernment adoption in Jordan

\section{Employees' Information Technology (IT) Skills}

Employee's IT skills are considered one of the primary components for successful e-government adoption (Williams et al., 2010; Zhang et al., 2011). Employees IT skills mean the ability of the employees to better implement online services and give better solutions. Basic level of education such as communication skills and using IT system is critical as it allows easy communication and appreciation of business 
terms in global business. Most organizations owner/managers, especially in developing countries, are unable to communicate in international languages that give access to global markets (Alghamdi et al., 2012). Thus, the following hypothesis can be derived:

H8: Employees' IT skills have a positive impact on egovernment adoption in Jordan

\section{Service Quality}

Several studies has shown that quality services offered by the public sector using new technology have been found to improve facility management and staff motivation at the same time (Krishnan et al., 2013). According to Parka and Raineyb (2012), quality services in the public sector yield positive outcomes in terms of performance and satisfaction. Thus, the following hypothesis can be derived:

H9: Service quality has a positive impact on e-government adoption in Jordan

\section{Efficiency}

Efficiency refers to the accuracy and completeness with which users can achieve specific goals in the easiest way, better output, reduce the time and increase the job performance using the online services such as e-government (Carter and Belanger, 2005; Abanumy et al., 2005). Additionally, adopting an egovernment application creates efficiency through providing citizens with relatively cheap, fast, up to date information and transaction services.

Thus, the following hypothesis can be derived:

H10: Efficiency has a positive impact on e-government adoption in Jordan

\section{Trading Partners' Pressure}

Trading partners' pressure is the action taken by suppliers or customers to force governments to adopt e-government (Baldwin et al., 2012). Governments will usually want to develop and deepen a business relationship with the aim of establishing a long-lasting business partnership (Parker and Castleman, 2009). This idea works well if the business partner recognizes the strategic value and competitive advantage that this can bring to both governments, suppliers and customers. Thus, the following hypothesis can be derived:

H11: Trading partners' Pressure has a positive impact on e-government adoption in Jordan

\section{Regulatory Issues}

The Internet provides a powerful tool for reinventing new rules and regulations to govern the adopting of new applications such as e-government (Ho, 2002). These rules and regulations involve as example but not limited to issues related to privacy and security protection and payment gateways. The main purpose of the e-government rules is to protect governments, businesses and citizens at the same time. Basu (2004; Al-Yaseen et al., 2013) have noted that the lack of regulatory policies have delayed many governments especially in developing countries from participating in e-government activities. Thus, the following hypothesis can be derived:

H12: Regulatory issues have positive impact on egovernment adoption in Jordan

\section{E-government Evaluation Measurement}

Measurement is important, since it allows for assessing the performance of the implementation of new technology, such as e-government. This is used for improvement purposes and for the establishment of clear service delivery standards (Hughes and Smart, 2012). According to performance measurement is a critical part of evaluation especially in the current changing business environment. In this research study, the Balance Score Card (BSC) indicators for Kaplan and Norton (1996) are adopted to measure e-government performance in Jordan. The BSC is considered the most widespread performance measurement tool developed that is used to evaluate innovation adoption success such as ecommerce and e-government (Martinsons et al., 1999; Hasan and Tibbits, 2000; Milis and Mercken, 2004; Kettunen and Kantola, 2005). It was originally designed for and tested in private sector organizations. According to Kaplan and Norton (1996) the BSC consists of four perspectives that include: Financial perspective, customer perspective, internal business perspective and the innovation and learning perspective. Several questions were given to respondents covering Kaplan and Norton indicators to measure e-government performance.

\section{Methodology}

In this research study the quantitative research is used to quantify the research problem by generating numerical data or data that can be transformed into useable statistics (Babbie, 2004). The researcher decided to rely on the quantitative method and develop a questionnaire to collect the relevant data from the target population. Therefore, a questionnaire was developed and distributed to the research population.

The population of this study consists of the three major e-government entities that are offering their services using e-government technology in Jordan. These include the municipality of Amman, licenses and 
vehicle department and the tax department. These entities will be examined through their departments that include IT department, operation, marketing, financial, human resources and auditing. Managers of these departments are the unit of analysis. Due to time and cost limitations, a sample that represents the population is chosen. The researcher intended to use the non- probability sampling, choosing the convenience sampling approach because of its convenient accessibility and proximity to the researcher (Malhotra, 2004; Bryman and Bell, 2007).

The study sample constitutes of senior employees and employees who carry managerial positions from all departments. The population for this study is estimated to be around 824 and since it's too large to be surveyed, a sample is taken to represent the population. In order to determine the sample size from a known population size, the researcher used the formulas given by Krejcie and Morgan (1970). According to Krejcie and Morgan table and based on the population size; the required sample size is set to be 248. The questionnaires were sent to subjects mostly online. In addition, the researcher used other methods to send the questionnaires such as post, fax and in person. From the 380 questionnaires sent to participants only 238 were returned. 9 questionnaires were considered invalid and only 229 questionnaires were carried for further analysis.

\section{Descriptive Statistics of the Research Sample}

Descriptive analysis was used to obtain frequency distribution. A series of questions were included in the first part of the questionnaire-survey to assess the nature of the respondents. This part was designed to obtain general information about the three Jordanian entities. According to the survey's results, entities established 11-15 years have the high response rate of $43 \%$, entities that have employees between 50-99, employees who work in the administration department have the most response rate of $29 \%$. In addition, the highest level of involvement in the decision making to e-government implementation in the surveyed entities was for employees who are frequently involved in the decision making with response rate of $37.3 \%$.

\section{Testing the Research Hypotheses}

In this research, the researcher used the stepwise regression analysis since it is a semi-automated process of building a model by successively adding or removing variables based solely on the t-statistics of their estimated coefficients (Hair et al., 1998). Based on the literature, 12 hypotheses that represent 12 variables were raised as discussed above. The variables (independent variables) will be tested against the e-government implementation success (dependent variable). Several rounds of the stepwise multiple linear regressions will be applied to test the hypotheses until the loading of the whole variable becomes significant and the P-value $<0.05$.

\section{Stepwise Multiple Linear Regressions}

The results of the stepwise regressions for the 12 independent variables that make up the original model identified 9 variables that have a significant effect in predicting e-government implementation success with pvalues $<0.05$ as summarized in Table 1 . These variables are trust, ease of use and access to internet, information technology, relative advantage, top management support, government structure, efficiency, service quality and regulatory issues.

The non-significant variables that were excluded from the original model with p-values $>0.05$ are 3 as shown in Table 2. These variables are employees' skills, sector size and trading partners' pressure. These variables were excluded and a second round of stepwise multiple linear regression was applied to the remaining independent variables.

Table Results of the stepwise regression that shows the significant variables of the research model -First round-

\begin{tabular}{|c|c|c|c|c|c|}
\hline \multirow[t]{2}{*}{ Model } & \multicolumn{2}{|c|}{ Unstandardized } & \multicolumn{3}{|c|}{ Standardize coefficients } \\
\hline & B & Std. Error & Beta & $\mathrm{t}$ & Sig. \\
\hline Information technology & 0.093 & 0.023 & 0.102 & 4.318 & 0 \\
\hline Relative advantage & 0.063 & 0.015 & 0.992 & 3.289 & 0 \\
\hline Top management support & 0.032 & 0.013 & 0.072 & 2.712 & 0.007 \\
\hline Government structure & 0.057 & 0.014 & 0.109 & 4.013 & 0 \\
\hline Efficiency & 0.073 & 0.021 & 0.085 & 4.543 & 0.003 \\
\hline Service quality & 0.081 & 0.027 & 0.101 & 4.565 & 0 \\
\hline Regulatory issues & 0.035 & 0.022 & 0.107 & 4.648 & 0.001 \\
\hline Trust & 0.063 & 0.019 & 0.113 & 3.193 & 0.001 \\
\hline $\begin{array}{l}\text { Ease of use and access to internet } \\
\text { a. Dependent Variable: (E-governt }\end{array}$ & $\begin{array}{l}0.059 \\
\text { nt succe }\end{array}$ & 0.013 & 0.129 & 4.671 & 0 \\
\hline
\end{tabular}


Table 2. Results of the stepwise regression that shows the excluded variables from the research model- First round

Excluded variables

\begin{tabular}{lllll} 
Model & Beta in & $\mathrm{t}$ & Sig. & Partial correlation \\
\hline Employee's skills & -0.015 & -0.635 & 0.495 & -0.065 \\
Sector size & 0.065 & 1.34 & 0.0654 & 0.187 \\
Trading partners' pressure & 0.068 & 1.669 & 0.089 & 0.152 \\
Dependent variable: (E-government success) & & & & \\
\hline
\end{tabular}

A second round of the stepwise multiple linear regression analysis tests were applied to the 9 independent variables generated from round one. Result shows that all 9 independent variables from round one have $p$-values $<0.05$, which indicated that all variables are important in predicting the dependent variable and confirm that no more rounds are needed.

\section{Discussion of the Hypotheses Testing}

According to the results of the stepwise multiple linear regression, detailed interpretation of the outputs of the final round are discussed in three sections. These include checking the assumptions, evaluating the model and assessing the importance of the independent variables. Discussing these sections will determine the supported hypotheses.

\section{Checking the Assumptions}

There are 3 assumptions to address in order to assure that the research is meeting the basic requirement of the multiple linear regression analysis. These assumptions relate to sample size, multicollinearity and normality. Sample size, with 229 respondents and 9 independent variables (second round), the cases to independent variables ratio is 25.4 to 1 , well above the minimum ratio for multiple linear regressions as suggested by Hair et al. (1998). Multicollinearity can be tested by examining the Tolerance value and the Variance Inflation Factor (VIF) value. The results shows that the tolerance value is more than 0.10 and the VIF value is less than 10.0 for each independent variable which means that no singe of statistical significant multicollinearity exists. Normality can be assessed by obtaining skewness and kurtosis value (Pallant, 2001). The values of skewness and kurtosis suggested a very good closeness to the normality of data distribution belonging to the e-government adoption.

\section{Evaluating the Model}

The model summary in Table 3 includes the value of $\mathrm{R}$ square that shows how much the variance in the dependent variable (e-government adoption) is explained by the 9 independent variables (Trust, ease of use and access to internet, information technology, relative advantage, top management support, government structure, efficiency, service quality and regulatory issues). The $\mathrm{R}$ square value is 0.958 , which means that the research model (which includes all the independent variables) explains $95.8 \%$ of the variance in e-government implementation success.

\section{Assessing the Importance of the Independent Variables}

Evaluating the importance of each independent variable on predicting e-government implementation success within Jordanian entities can be examined by the coefficient table obtained from the analysis. The coefficient table revealed two important results. First, beta values (standardized coefficients) can be used to compare the importance of each predictor in the model by examining each individual $t$ test. Second, B values (unstandardized coefficients) can be used to construct the regression equation.

The coefficient table, Table 1, shows that the largest beta coefficient is 0.129 which is for ease of use and access to internet. This means that this variable makes the strongest contribution to predict and explain egovernment implementation success within Jordan. The second beta coefficient is for trust with beta coefficient 0.113 followed by government structure with beta coefficient of 0.109 and then regulatory issues with beta coefficient of 0.107 and this was followed by information technology with beta coefficient of 0.102 and this was followed by service quality with beta coefficient of 0.101 and this was followed by relative advantage with beta coefficient of 0.099 . The lowest predictors are efficiency and top management support with beta coefficient of 0.085 and 0.072 respectively. The coefficient table, Table 1, also shows that the p-values for all independent variables are less than 0.05 , indicating that these variables significantly contribute to the equation.

\section{Benefits of E-government Implementation}

Managers who participated in the questionnaire were given a list of seven potential e-government benefits and were asked to rank them according to their own experiences. The questions aimed to examine and analyze how the respondents ranked the benefits associated with e-government implementation (Layne and Lee, 2001; Olatokun and Bankole, 2011). The respondents' answers in the scale ranged from one, 'negative effects' to five, 'very beneficial effects'. Table 4 shows a summary of the rank order of the seven potential benefits, means and standard deviations. 
Table 3. Model summary

\begin{tabular}{lllll}
\hline Model & R & R square & Adjusted R square & Std. Error of the estimate \\
\hline & 0.979 & 0.958 & 0.948 & 0.13199
\end{tabular}

a. Dependent variable: (E-government success)

Table 4. Major benefits of E-government implementation

\begin{tabular}{llll}
\hline Benefits & $\mathrm{N}$ & Ranking & Mean \\
\hline Improving the competitive position of the government entity & 1 & 2 & 4.09 \\
Building trust with customers & 2 & 4 & 4.07 \\
Building trust with suppliers & 3 & 6 & 3.87 \\
Reducing operational costs & 4 & 3 & 0.781 \\
Reducing the workforce & 5 & 5 & 0.852 \\
Providing a more reliable service to customers & 6 & 1 & 4.05 \\
Improving the image of the government entity & 7 & 7 & 4.11 \\
\hline
\end{tabular}

Table 5. Major barriers of e-government implementation

\begin{tabular}{|c|c|c|c|c|}
\hline Barriers & $\mathrm{N}$ & Ranking & Mean & Std. Deviation \\
\hline Speed of Internet services & 1 & 4 & 3.8 & 1.04 \\
\hline Internet infrastructure in the country & 2 & 5 & 3.4 & 0.75 \\
\hline Cost of maintaining the website & 3 & 7 & 3.1 & 0.81 \\
\hline Difficulty of maintaining the website & 4 & 1 & 4.6 & 0.72 \\
\hline Lack of electronic payment systems & 5 & 2 & 4.5 & 0.63 \\
\hline Percentage of customers with Internet access & 6 & 6 & 3.3 & 0.94 \\
\hline Ineffective and inefficient storage and delivery system & 7 & 3 & 4.2 & 0.74 \\
\hline
\end{tabular}

Providing more reliable service to customers was the most benefit that may encourage Jordan's government to implement e-government technology and it was ranked the first with a mean of (4.11) as shown in Table 4. This was followed by Improving the competitive position of the government entity with mean value of (4.09) followed by reducing the workforce with mean value of (4.08) followed by building trust with suppliers with mean value of (4.07) and then followed by Reducing the workforce with mean value of (4.05). This was followed by Building trust with suppliers with mean value of (3.87) and finally improving the image of the entity was ranked at the bottom level with a mean value of (3.82).

\section{Barriers to E-government Implementation}

Managers who participated in the questionnaire were also given a list of seven potential barriers questions and were asked to rank them in the light of their own experiences. The questions aimed to examine and analyses how the respondents ranked the obstacles associated with e-government implementation (Lam, 2005; Kshetri, 2007; Lawrence and Tar, 2010). The respondents' answers in the scale ranged from one, 'not a constraint at all', to five, 'very strong constraints that prevented us implementing some aspects of e-government'. Table 5 shows a summary of the rank order of the seven potential obstacles, means and standard deviations.

Table 5 shows that the difficulty of maintaining the website was the most barriers to e-government implementation and it was ranked the first with a mean of (4.6) followed by the lack of electronic payment systems with mean value of (4.5). This was followed by ineffective and inefficient storage and delivery system with mean value of (4.2) followed by speed of internet services with mean value of (3.8) followed by internet infrastructure in the country with mean value of (3.4) followed by percentage of customers with internet access with mean value of (3.3). Finally cost of maintaining the website was ranked the lowest barrier with mean value of (3.1).

\section{Conclusion}

The originality of this research is represented in a quantitative survey to describe the current state of Jordan's e-government and the mutual interaction between the government and its citizens. From the research analysis conducted in this study, only 9 factors out of 12 are found to be supported and affect the successful implementation of e-government within Jordan.

Ease of use and access to internet variable makes the strongest contribution to predict and explain egovernment implementation success within Jordan. Based on the analysis test applied to the original model, the responses of the Jordanian organizations did express the importance of Usability and accessibility of internet for e-government implementation success and this result was supported by Weerakkody et al. (2007) and Sajuyigbe (2012). The findings of the analysis indicated that there is a strong relationship between the trust factor and the successful implementation of e-government and this is consistent with the findings of Aljafri et al. (2013). 
In addition, the findings of the process of analysis indicated that information technology, relative advantage, top management support, government structure, efficiency, service quality and regulatory issues have also strong influence on e-government diffusion. The result of the analysis is consistent with the findings of (Lin et al., 2011; Banerjee and Ma, 2012; Wang et al., 2010; Krishnan et al., 2013; Basu, 2004).

Unfortunately, top management support was ranked the lowest influential factor which means there is not enough commitment from the management side to support the adoption of the new technology.

The findings of the process of analysis indicated that no relationship exists between the employee's skills, sector size and trading partners' pressure and the successful implementation of e-government. This result was not supported by (Banerjee and $\mathrm{Ma}, 2012$; Alghamdi et al., 2012; Parker and Castleman, 2009).

There is no benefit of allocating resources for training employees to improve their skills since the analysis showed that this variable is not important for the decision makers in Jordan. The research also revealed unexpected result of having no pressure from other companies and/or suppliers and customers to force the government of Jordan to adopt E-government.

In addition, the size of the entity is no longer considered important for e-government adoption. In terms of the benefits and barriers, providing a more reliable service to customers was the most benefit that may encourage Jordan's entities to implement E-government. Managers at Jordan's entities also stated that the difficulty of maintaining the website is considered the most barriers that inhibit e-government implementation.

\section{Acknowledgement}

I would like to express my special thanks of gratitude to many great people have inspired us to complete this project. Thanks to all interview participants who showed a great deal of cooperation and shared frankly their thorough experiences with us to obtain the required data. For them we are greatly indebted.

\section{Funding Information}

This study was done by self-financing.

\section{Author's Contributions}

Author solely accomplished this article.

\section{Ethics}

We confirm that this manuscript has not been published elsewhere and is not under consideration by another journal. Each author confirms the manuscript represents honest work. All authors have approved the manuscript. Each author agrees with the order in which his name appears on the title page.

\section{References}

Abanumy, A., A. Albadi and P. Mayhew, 2005. EGovernment website accessibility: In-depth evaluation of Saudi Arabia and Oman. Electronic J. e-Government, 3: 99-106.

Ahmad, A. and S. Zink, 1998. Information technology adoption in Jordanian public sector organizations. J. Government Information, 25: 117-134.

Al-Abdallah, G.M., 2013. The effect of customercompany relationship on internet adoption in Jordanian small and medium enterprises. J. Economics Behavioral Studies.

Alghamdi, I.A., V Goodwin and G. Rampersad, 2012. Egovernment readiness assessment for government organizations in developing countries. Computer Information Sci., 4: 3-17. DOI: 10.5539/cis.v4n3p3

Al Hujran, O., A. Aloudat and I. Altarawneh, 2013. Factors inuencing citizenadoption of e-government in developing countries: The case of Jordan. Int. J. Technol. Human Interaction, 9: 1-19. DOI: $10.4018 /$ jthi.2013040101

Aljafri, A., A. Pons and D. Collins, 2013. Global egovernment: A framework for understanding Computer security. DOI: $10.1108 / 09685220310480417$

Al-Jaghoub, S. and C. Westrup, 2003. Jordan and ICTled development: Towards a competition state? Information Technol. People, 16: 93-110. DOI: $10.1108 / 09593840310463032$

Al-Khouri, A.M. and J. Bal, 2007. Electronic government in the GCC countries. Int. J. Social Sci., 1: 83-98

Almatarneh, A., 2011. Privacy implications for Information and Communications Technology (ICT): The case of the Jordanian e-government. J. Int. Commercial Law Technol., 6: 151-164.

Al-Qirim, N., 2007. The adoption and diffusion of Egovernment in developing countries: The case of NGO in Jordan. Information Technol. Development, 13: 107-131. DOI: 10.1002/itdj.20053

Alsaghier, H., M. Ford, A. Nguyen and R. Hexel, 2009. Conceptualizing citizen's trust in e-government: Application of Q methodology. Electronic J. EGovernment, 7: 295-310.

Alshehri, M., S. Drew and O. Alfarraj, 2012. A comprehensive analysis of e-government services adoption in Saudi Arabia: Obstacles and challenges. Int. J. Adv. Comput. Sci. Applic., 3: 1-6. DOI: 10.1.1.259.3032

Al Shibly, H. and I. Tadros, 2010. Employee's perceptions towards electronic government in Jordan. European J. Scientific Research, 48: 169-176. 
Al-Soud, A. and K. Nakata, 2010. Evaluating egovernment websites in Jordan: Accessibility, usability, transparency and responsiveness. Proceedings of the 2010 International Conference on Progress in Informatics and Computing (PIC' 10), Shanghai, pp: 761-765.

Al-Yaseen, H., A. Al-Soud and S. Al-Jaghoub, 2013. Assessing Jordan's e-government maturity level: Citizen's perspective on awareness, acceptability and usage of e-government services. Int. J. Electronic Govt. Res. IGI Global. DOI: $10.4018 /$ ijegr.2013100101

Anas, R.A.S., H. Al-Yaseen and S.H. Al-Jaghoub, 2014. Jordan's e-Government at the crossroads. Transform. Govt. People, Process Policy, 8: 597-619. DOI: $10.1108 /$ TG-10-2013-0043

Arif, M., 2008. Customer orientation in e-government project management: A case study. Electronic J. eGovernment, 6: 1-10.

Babbie, E., 2004. The Practice of Social Research. 10th Edn., Oxford University Press.

Baldwin, J.N., R. Gauld and S. Goldfinch, 2012. What public servants really think of e-government. Public Management Rev., 14: 105-127.

DOI: $10.1080 / 14719037.2011 .589616$

Banerjee, P. and L. Ma, 2012. Reutilization of B2B Egovernment by small firms: A process perspective. Information Systems Frontiers.

Basu, S., 2004. E-government and developing countries: An overview. Int. Rev. Law, Computers Technol., 18: 109-132. DOI: 10.1080/13600860410001674779

Beynon-Davies, P., 2007. Models for e-government. Transforming Government: People, Process Policy, 1: 7-28. DOI: 10.1108/17506160710733670

Bryman, A. and E. Bell, 2007. Business research methods. 2nd Edn., Oxford University Press.

Carter, L. and F. Bélanger, 2005. The utilization of egovernment services: Citizen trust, innovation and acceptance factors. Information Syst. J., 15: 5-25. DOI: $10.1111 / \mathrm{j} .1365-2575.2005 .00183 . \mathrm{x}$

Carter, L. and V. Weerakkody, 2008. E-government adoption: A cultural comparison. Information Syst. Frontiers, 10: 473-482. DOI: $10.1007 / \mathrm{s} 10796-008-9103-6$

Ciborra, C. and D. Navarra, 2005. Good governance, development theory, and aid policy: Risks and challenges of e-government in Jordan. Inform. Technol. Develop., 11: 141-159. DOI: $10.1002 /$ itdj.20008

DOS, 2016. Department of Statistics Jordan (DOS).

Ebrahim, Z. and Z. Irani, 2005. Egovernment adoption: architecture and barriers. Bus. Process Manage. J., 11: 589-611.

Gauld, R. and S. Goldfinch, 2006. Dangerous enthusiasms: E-government, computer failure and information system development. Dunedin, New Zealand. Social Sci. Comput. Rev., 26: 257-259.
Grimsholm, E. and L. Poblete, 2010. Internal and External factors hampering SME growth -A qualitative case study of SMEs in Thailand. MSc. Thesis, Business Administration 15 ECTS.

Hair, J., R. Anderson, R. Tatham and C. William, 1998. Multivariate data analysis. Upper Saddle River, NJ: Prentice Hall.

Hasan, H. and H. Tibbits, 2000. Strategic management of electronic commerce: An adaptation of the balanced scorecard. Internet Res., 10: 439-450.

Ho, A., 2002. Reinventing local governments and the egovernment initiative. Public Admin. Rev., 62: 434-444. DOI: 10.1111/0033-3352.00197

Hsieh, Y.Y., P.H. Hung and J.Y. Leu, 2013. Hsp90 regulates nongenetic variation in response to environmental stress. Molecular Cell, 50: 82-92. DOI: 10.1016/j.molcel.2013.01.026

Hughes, P. and J. Smart, 2012. You say you want a revolution' ... the next stage of public sector reform in New Zealand. Policy Q., 8: 3-8.

Iddris, F., 2012. Adoption of E-government solutions in small and medium-sized enterprises in Jordan. European J. Business Management.

Kaplan, R. and Norton, D. 1996. Focusing your organization on strategy with the balance scored card. 2nd Edition. Harvard Business Review

Kettunen, J. and I. Kantola, 2005. Management information system based on the balanced scorecard. Campus-Wide Inform. Syst., 22: 263-274.

Krejcie, R. and D. Morgan, 1970. Determining sample size for research activities. Educ. Psychol. Measure. DOI: $10.1177 / 001316447003000308$

Krishnan, S., T.S.H. Teo and V.K.G. Lim, 2013. Examining the relationships among e-government maturity, corruption, economic prosperity and environmental degradation: A cross-country analysis. Inform. Manage., 50: 638-649.

DOI: $10.1016 /$ j.im.2013.07.003

Kshetri, N., 2007. Barriers to E-government and competitive business models in developing countries: A case study. Electron. Commerce Res. Applic., DOI: 10.1016/j.elerap.2007.02.004

Lam, W., 2005. Barriers to e-government integration. Enterprise Inform. Manage., 18: 511-530.

Laudon, K. and C. Traver, 2009. E-government: Business, Technology, Society. 5th Edn. Prentice Hall, New Jersey.

Lawrence, J. and U.A. Tar, 2010. Barriers to commerce in developing countries. Information, Society and Justice.

Layne, K. and J. Lee, 2001. Developing Fully Functional E-government: A four stage model. Government Inform. Q., 18: 122-136. DOI: $10.1016 / \mathrm{S} 0740-624 \mathrm{X}(01) 00066-1$

Leonard, L., 2012. Attitude influencers in C2C Egovernment: Buying and selling. J. Comput. Inform. Syst. 
Lin, Y.R., K. Kim, Y. Yang, A. Ivessa and J. Sadoshima et al., 2011. Regulation of longevity by regulator of G-protein signaling protein, Loco. Aging Cell, 10: 438-447.

Malhotra, N., 2004. Marketing Research: An Applied Orientation. 4th Edn., Prentice-Hall International, London.

Martinsons, M., R. Davison and D. Tse, 1999. The Balanced scorecard: A foundation for the strategic management of information systems. Decision Support Syst., 25: 71-78. DOI: 10.1016/S0167-9236(98)00086-4

Mofleh, S., M. Wanous and P. Strachan, 2008. Developing countries and ICT Initiatives: Lessons learnt from Jordan's experience. Electronic J. Inform. Syst. Develop. Countr., 34: 1-17.

Moon, M.J., 2002. The evolution of e-government among municipalities: Rhetoric or reality? Public Administration Rev., 62: 424-433.

DOI: $10.1111 / 0033-3352.00196$

Molla, A. and P.S. Licker, 2009. Perceived-readiness factors in e-government adoption: An empirical investigation in developing country. Int. J. Electronic Commerce.

Molla, A. and P. Licker, 2005. E-government adoption in developing countries: A model and instrument. Inform. Manage., 42: 877-899.

Milis, K. and R. Mercken, 2004. The use of the Balanced Scorecard for the evaluation of Information and Communication Technology projects. Int. J. Project Manage., 22: 87-87. DOI: $10.1016 / \mathrm{S} 0263-7863(03) 00060-7$

Nassuora, N. and A. Al-Mushasha, 2012. Factors determining e-learning service quality in Jordanian higher education environment. J. Applied Sci., 12: 1474-1480. DOI: 10.3923/jas.2012.1474.1480

Olatokun, W. and B. Bankole, 2011. Factors influencing electronic business technology adoption and use by Small and Medium Scale Enterprises (SMEs) in a Nigerian Municipality. J. Internet Bank. Commerce.

Pallant, J., 2001. SPSS Survival Manual: A step by step guide to data analysis using SPSS. Open University Press, Buckingham, Phildelphia.
Parka, S.M. and H.G. Raineyb, 2012. Work motivation and social communication among public managers. Int. J. Hum. Resource Manage., 23: 2630-2660. DOI: $10.1080 / 09585192.2011 .637060$

Parker, C.M. and T. Castleman, 2009. Small firm e-business adoption: A critical analysis of theory. J. Enterprise Inform. Manage., 22: 167-182. DOI: $10.1108 / 17410390910932812$

Peng, F and S. Kurnia, 2010. Understanding hospital information systems adoption in China. PACIS.

Prajogo, D. and J. Olhager, 2012. Supply chain integration and performance: The effects of longterm relationships, information technology and sharing and logistic integration. Int. J. Product. Econom. DOI: 10.1016/j.ijpe.2011.09.001

Ripolles, M., P. Blesa and D. Roing, 2010. The Influence of innovation orientation on the internationalisation of SMEs in the service sector. Services Industries J., 30: 777-791. DOI: 10.1080/02642060802342679

Sajuyigbe, A.S., 2012. Adoption of E-government to business operations: A key to achieving Nigeria Vision.

Wang, Q., M. Uhlirova and D. Bohmann, 2010. Spatial restriction of FGF signaling by a matrix metalloprotease controls branching morphogenesis. Dev. Cell, 18: 157-164.

Weerakkody, V., S. Jones and E. Olsen, 2007. EGovernment: A comparison of strategies in local authorities in the UK and Norway. Int. J. Electronic Business, 5: 141-159. DOI: 10.1504/IJEB.2007.012970

Williams, R., T. Van der Wiele, J.V. Iwaarden and S. Eldridge, 2010. The importance of user-generated content: The case of hotels. Total Quality Manage. J., 22: 117-128.

Zhang, Z., Z. Tian and X. Guan, 2011. A new evolution mechanism model for B2B e-government network. J. Electronic Commerce Organizations. 